\title{
Software Process Models and Agile Method Applicability in Industry
}

\author{
Mahmut Ünver \\ Lecturer, Department of Computer Programming, \\ Kırıkkale University, Kırıkkale, Turkey
}

\begin{abstract}
Software process models have been developed since 1968. When software process models are implemented in the software sector, it is considered that more suitable projects will be developed in terms of customer satisfaction and cost. In this study, the use of Agile, which is a frequently used software process model, in industry is investigated. In the research, software process models are explained and industrial sectors using Agile method are examined. It has been observed that customer satisfaction, time saving, and project success increase in sectors where Agile method is applied. Likewise, the project has also increased efficiency and competence.
\end{abstract}

Key Words: Software Process Model, Agile Method, Waterfall Model, Software, Industry Software

\section{INTRODUCTION}

The software development process is extremely difficult and important process. At the end of this process, the project delivered to the customer must be successful. However, some projects fail and cannot be used, so resources are wasted. According to CHAOS reports on the success rates of software projects published by Standish Group International every year since 1994, the success rates of software projects between 2009 and 2015 are presented in Table 1 [1].

\section{Table 1: CHAOS Reports Success Rates between} 2009-2015.

\begin{tabular}{|c|c|c|c|c|c|c|}
\hline & 2009 & 2011 & 2012 & 2013 & 2014 & 2015 \\
\hline $\begin{array}{c}\text { Successful } \\
\text { Projects }\end{array}$ & $32 \%$ & $29 \%$ & $27 \%$ & $31 \%$ & $28 \%$ & $29 \%$ \\
\hline $\begin{array}{c}\text { Additional } \\
\text { Costs }\end{array}$ & $44 \%$ & $49 \%$ & $56 \%$ & $50 \%$ & $55 \%$ & $52 \%$ \\
\hline $\begin{array}{c}\text { Failed } \\
\text { Projects }\end{array}$ & $24 \%$ & $22 \%$ & $17 \%$ & $19 \%$ & $17 \%$ & $19 \%$ \\
\hline
\end{tabular}

Successful projects stated in the CHAOS reports are projects that have achieved within the planned time and without exceeding the planned budget. Troubled projects are projects that have been completed but not finished on time as planned or exceeds project budget limit or have not reached their goals in terms of requirements and functions. Failed projects are canceled or incomplete projects.

The reasons for the failure of the projects can be listed as various problems such as the inability to reveal software versions in a timely manner, failure to respond to change requests quickly, late detection of software errors, and failure to develop the system according to incoming requests [2].

To eliminate failures, companies need active software systems to manage business processes, and they either produce this software through information system departments or supply software from software companies. In both cases, the production of software requires a series of engineering and project management processes. The methodology of these processes, the size of the software to be produced, the complexity, the characteristic features such as the purpose of use, the structure of the organization and project team that will produce the software and the resources that can be used are important [3].

The software development process began in 1968 with the Software Engineering Congress organized by the North Atlantic Treaty Organization (NATO) Science Committee in Germany. In 1970, Winston Royce published the Waterfall software development method with the article he published [4]. This method also refers to customer satisfaction. This has been an important factor in the Agile method used today. 
As a result of the efforts to overcome these problems, methods named as agile have been developed towards the end of the 1990s [2].

Agile method, unlike other methods, can be used as a suitable software development process in small enterprises, and they aim to produce products very quickly, respond quickly to changing requests and offer a software product to the customer service as soon as possible $[5,6]$.

In their study, Vijayasarathy and Turk evaluated the adaptation and use of agile software development method in terms of early adopters. Agile's submethods XP and test-first are the most common software development approach. SCRUM, on the other hand, explained in fourth place. The majority of participants $(75 \%)$ stated that they used agile methods in their projects [7].

In 2011, Azizyan, Magarian and Kajko-Mattson conducted a study on the need and use of tools with more agile approaches. In this study, SCRUM with $54 \%$ and with $32 \%$ concluded that XP was the most common Agile methods. For the tools used, they showed that' 26 classic adhesive papers, MS Excel with $23 \%$ and MS Project with $8 \%$ were used [8].

According to the results of a research conducted by Digital Focus in 2006, $81 \%$ of the companies participating in the project are working or using the agile method. $51 \%$ of these companies think that they cannot use the agile method because of lack of knowledge and skills $[9,10]$.

\section{SOFTWARE PROCESS MODELS}

Software project processes are difficult processes in terms of management. Because software projects are primarily a project and must remain alive and meet customer needs. The reason why it is difficult is to try to keep pace with the changing and growing needs of the systems quickly and reliably.

At software life cycle are available that analysis, design, software development and testing stages. For the analysis of successful projects, $70 \%$ rate of the time and labor are spent. The remaining time is $10 \%$ design, $10 \%$ software and $10 \%$ acceptance test. Project management is a necessity for the successful operation of the works throughout the process.
The software life cycle found in quality projects coincides with the PACT (Plan, Apply, Check, Take Precaution) cycle which aims to improve continuously. In this way, it is possible to allocate time for the research and development studies required by the technology while the whole team is able to adapt to new developments and achieve their goals with increasing successes.

In summary, a software development methodology consists of the following steps:

$>$ A software development philosophy with a software development process approach.

Tools, models and methods that support software development process.

The most common software development models are:

$>$ Waterfall Model

$>$ Agile Software Prosess

$>$ V Model

$>$ Incremental Model

Spiral Model

Waterfall model is used in traditional software development processes.

\subsection{Waterfall Model}

As shown in Figure 1, the Waterfall model continues downward (like a waterfall) along the phases of software development, such as requirement analysis, design, development, testing and maintenance. Sequential development process.

Activities at every step of the waterfall are fully fulfilled. This is a condition for moving to the next level. A document is created at the end of each phase.

So, the waterfall model is document-guided. The software process is linear, meaning that the activities in the previous phase must be completed in order to proceed to the next stage. User involvement is possible during the initial phase. User requirements are identified and detailed at this stage. Dialogue with customers and users is not allowed in the subsequent design and coding phases. 


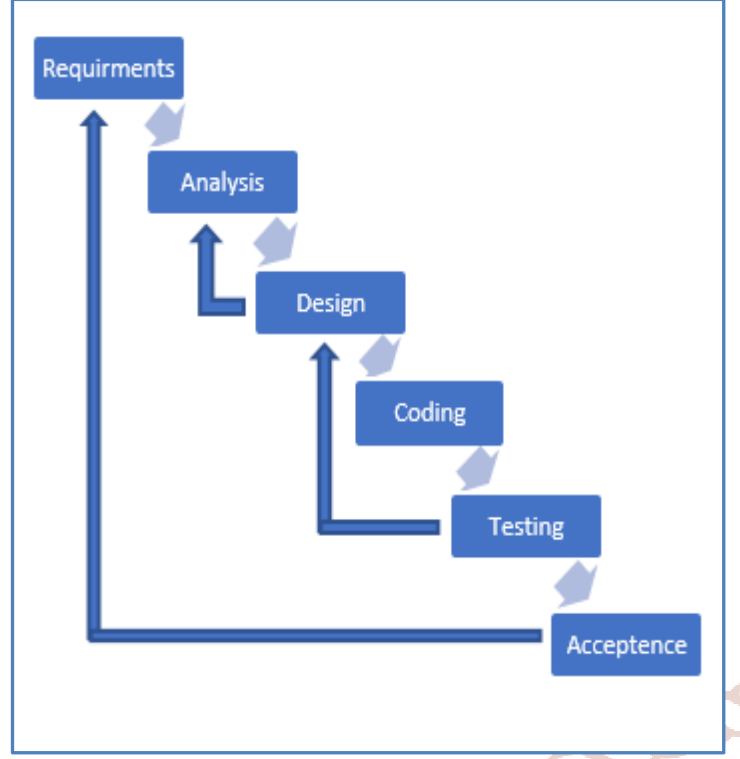

Figure1. Waterfall model structure

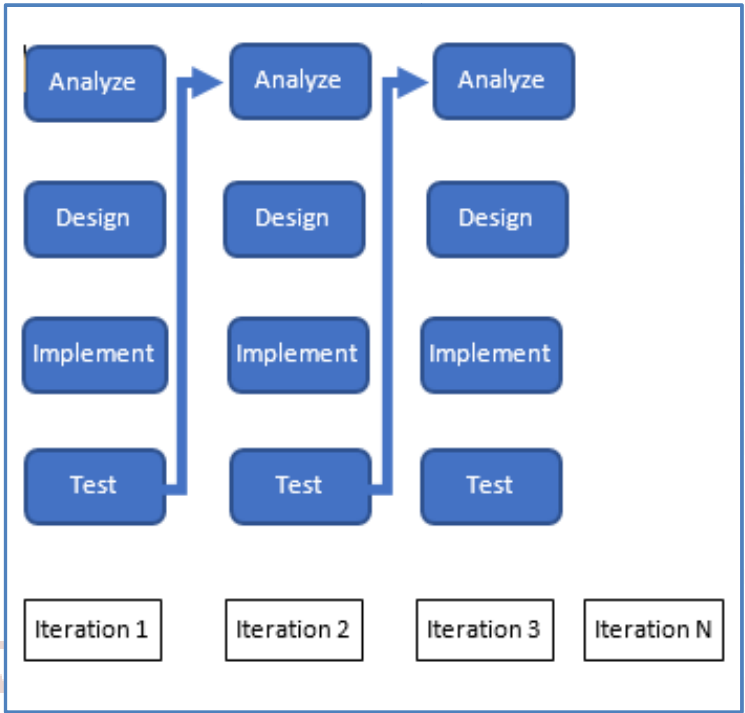

Figure2: Agile method structure
Failure to switch to another phase before a phase ends requires that the client identify all the requirements in the first stage. At the beginning of the project, customers are not $100 \%$ sure what exactly they want. Therefore, as the project develops, customers can change requests. determination of errors that at start may take a very long time. Eliminating these errors will increase the cost.

\subsection{Agile Method}

In 2001, 17 software experts came together and consisted of 12 items, in short, Agile Manifest known as the "Agile Software Development" manifest issued a statement.

Although Agile Methods seems to be softwareoriented, it has become useable at different sectors as well.

The most popular Agile methodologies are Scrum and Kanban. Later, Scrumban emerged from the combination of these.

Content Management Practices:

$>$ Scrum

$>$ Kanban

$>$ Scrumban

Engineering Practices:

$>$ XP (Extreme Programming)

$>$ BDD (Behaviour Driven Development)

$>$ TDD (Test Driven Development)

$>$ Design Patterns

$>$ Continuous Integration [11]
Agile project management is an iterative and incremental project management method that can be used to develop software projects. Figure 2 shows the general structure of the Agile method. Agile methods are advantageous in order to be able to produce products very quickly, respond quickly to changing requests and offer a software product to customer service as soon as possible. On the other hand, with the increase in the use of agile methods in the management of software projects, some problems have been seen in project management [5].

\subsection{Spiral Method}

The spiral software development model basically includes four main sections. These can be defined as planning, risk management, production and user evaluations. Planning includes planning activities for the intermediate product to be produced, determining objectives and constraints and alternatives, integrating with the product produced in the previous step. In risk management, alternatives are evaluated, and risk analysis is performed. Production is the stage at which the planned intermediate product is developed. After this stage, in the user evaluation section, the users are tested and evaluated about the intermediate product.

\subsection{Model}

The V-model offers a software development process that can be thought of as the advanced version of the waterfall model. Instead of moving in a linear direction, the process steps are tilted upward after the coding phase and form the typical V shape. V-Model shows the relationships between each phase of development life cycle. Horizontal and vertical angles 
indicate the time or completeness of the project and the abstract level.

\section{APPLICATIONS OF AGILE METHOD IN INDUSTRY}

Agile method has been used in defense industry. In their study, Burcu Nalbant and Mert Bıçakçı applied the Agile method in a private company to minimize the existing problems in defense projects. For example, the information transfer in the work done to reduce the communication gap between large teams was provided by short-term meetings held daily. The use of agile methods has also benefited in terms of the ability of the team members to see the works that will be done during the Sprint. Thus, the project management has been able to minimize the difference between planned and actual effort and comply with the schedule. In addition, risks were foreseen in time and necessary regulate could be taken [12].

Agile method has been applied in companies in manufacturing industry. G. Akman and G. A. Keskin in his work, they had performed survey work to determine the level perceived by small and medium enterprises in Turkey of agile manufacturing system which of a modern system. Hypothesis tests were applied to the data collected in the study. In this way, the relationship between total number of employees, sector and duration of activity was determined. As a result of the analysis, it has been found that agile production systems are new concepts in terms of firms operating in manufacturing sector. It has become clear that production systems have to undergo a certain period of time for the adoption and implementation of these concepts [13].

In the study performed of Sar1, the use of agile process approaches and Scrum $\mathrm{R} \& \mathrm{D}$ projects which is an agile process method, were analyzed. In the study, an R \& D software project was examined. As a result, it has been found that the use of Scrum agile approach method in $R \& D$ projects is quite beneficial. It has been observed that $\mathrm{R} \& \mathrm{D}$ projects will benefit at the solution of problems such as coordination problems and changing needs [14].

Together with the project examined, the benefits of using various auxiliary tools which are very important in practice of Agile method have been mentioned. Within the scope of the work, to embody them a research and development software developed by classical method has also been studied [14].

\section{RESULTS AND DISCUSSION}

In this study, software development processes are examined. The waterfall method is the first process developed in software development processes. Usually, other methods are methods that are used to reduce the negative aspects of the waterfall method. It is generally used as reference in software management process in public institutions and large-scale companies. Research on the use of these methods in industry was conducted. It has been observed that the use of the Agile method, which can be contacted with the customer for a shorter period than the waterfall method, which is generally used in the applications so far, is more suitable in the sector. Agile method is now preferred as software development process in projects to be produced in large companies. It is understood that it can be used in different sectors. In this study, the positive and negative aspects of waterfall, agile, V-model and spiral software development processes are explained and compared. In the study, it was determined that there is a positive and significant relationship between the subdimensions of agile production capacity, qualification, speed, flexibility and people and performance of new product.

\section{REFERENCES}

1. Standish Group International, CHAOS Report, https://www.standishgroup.com/outline [Access Date: 15.12.2018].

2. Highsmith, J., "Agile Software Development Ecosystems", Addison Wesley, 2002.

3. C. Gencer, A. Kayacan, Yazılım Proje Yönetimi: Şelale Modeli ve Çevik Yöntemlerin Karşılaştırılması, Bilişim Teknolojileri Dergisi, Vol. 10(3), 2017.

4. W.W. Royce, "Managing the Development of Large Software Systems", The Proceedings of the WESCON, San Francisco, USA, 328-339, 1970.

5. Boehm, B., Turner, R., Observation on Balancing Discipline and Agility, Proceedings of the Agile Development Conference, IEEE Computer Society, 2003.

6. K. Çamoğlu, D. Akbayıt, F. Yücalar, S. Bayraklı, Bir Çevik Yazılım Geliştirme Sürecinin Uyarlanması ve Uygulanması, Havacilik Ve Uzay Teknolojileri Dergisi, vol.4(3), pp. 57-67, 2010.

7. L. R. Vijayasarathy, D. Turk, Agile software development: A survey of early adopters. Journal 
of Infarmiation management, vol. 19(2), pp. 1-8. 2008.

8. G. Azizyan, M. K. Magarian, M. Kajko-Mattson, Survey of agile tool usage and needs. In: Agile Conference, pp. 29-38, 2011.

9. http://www.infoq.com/news/Digital-FocusUnveil-Survey-2006, D. H. Preuss, Digital Focus Unveils Market Survey Results at Agile 2006, [Access Date: 15.12.2018].

10. E. Çetin1, P. O. Durdu, Türkiye'de Çevik Yazılım Geliştirme Üzerine Bir İnceleme, 8th Turkish National Software Engineering Symposium (UYMS 2014), Güzelyurt, KKTC, Turkey, 2014. yonetimi/agile-cevik-yontemler/?i=1,

[Access Date: 15.12.2018].

12. B. Nalbant, M. Bıçakçı, Savunma Projelerinde Çevik Metodolojiler, 9th Turkish National Software Engineering Symposium (UYMS 2015), Izmir, Turkey, 2015.

13. G. Akman ve, G. A. Keskin, İmalat Firmalarinda Çevik Üretimin Algılanma Seviyesinin Değerlendirilmesi, Dumlupınar Üniversitesi Fen Bilimleri Enstitüsü Dergisi, vol.28, 2012.

14. Ö. Sarı, Scrum Çevik Süreçlerinin Ar-Ge Yazılım Projelerinde Kullanımı, Çevik Yaklaşımla Yazılım Geliştirme Çalıştayı, İzmir, 2013.

11. [Online] http://www.koksalgurkan.com/proje- 